\title{
AN ANALYSIS OF CODE-SWITCHING IN ENGLISH MEETING CLUB (Benteng Panynyua Club in Fort Rotterdam Makassar)
}

\author{
Juvrianto CJ \\ Universitas Negeri makassar \\ juvrianto.chrissunday@yahoo.com
}

\begin{abstract}
Code-Switching is a phenomenon that may occurs in Bilingual or Multilingual communities. Indonesian students who learn English as Foreign Language tend to find a way to master English by forming or joining an English Meeting Club. Code -Switching occurs when they try to speak English in their conversation. The aim of this study is to describe the type of Code-switching used by the members of English meeting club and reason why they did that switching. This research used qualitative method. The subject of the research was participants of English Meeting Club and the data of Code-switching are taken from recording which was converted into transcription. The result shows that the members of English meeting club did three types of Code-switching. Those are tag-switching, intra-sentential switching and intersentential switching. They mostly used intra-sentential switching in their conversation and did the switching to make their utterances acceptable to the hearer.
\end{abstract}

Keywords - Bilingualism, Code-Switching, English Meeting Club

\section{A. INTRODUCTION}

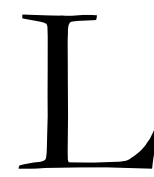

anguage is the most important means of human communication, and communication is the most important function of language. Therefore, the ultimate goal of language teaching is communicative competence (Liu, 2003). Communicative competence requires students to be able to use the language in real communication either spoken or written communication.

In Indonesia, English is learnt as demand of curriculum. It is placed as one of compulsory subject, but the status of English as foreign language in Indonesia makes Indonesian students quite difficult to mastery the language. As bilingual or multilingual country, Indonesian has had Bahasa Indonesia and their tight local languages such as Javanese, Sundanese, Buginese etc. and they have tied up with them.

However, to reach the ultimate goal of language teaching, class meeting in formal education is still not enough. Students need to practice and develop their English continuously outside of the class. That is why any English Courses and English meeting clubs are provided to minimize the difficulties that Indonesian students face in learning English. 


\section{Juvrianto CJ An Analysis Of Code-Switching...}

Indonesian students, who held English meeting clubs to develop their English skill, try to use English in every conversation they make. But as bilingualism or multilingualism community, there are some phenomena that may be occurred when they try to practice their English. One of the phenomena is code-switching.

Code-switching becomes an interesting phenomenon to be studied. it is a part of language learning process by people who learn more than one language (Bilingual or multilingual). Poplack (2001) stated that "Code-switching (CS) refers to the mixing, by bilinguals (or multilinguals), of two or more languages in discourse, often with no change of interlocutor or topic".

The study of code switching has been conducted by many scholars. There are some related researches have been done previously. First, the research that conducted by Koban (2013). He explored patterns of intra-sentential and inter-sentential code-switching that are occurred in the speech of Turkish-English bilinguals in New York, United States and investigated the influence of language proficiency on intra-sentential Switching. He found that intra-sentential Code-switching occurred at a higher rate than inter-sentential Code-Switching and speakers who dominant in both Turkish and English used more intra-sentential code switching than inter-sentential Codeswitching.

The second research is from Azlan \& Narazuman (2013). The research was entitled "The Role of Code-Switching as a Communicative Tool in an ESL Teacher Education Classroom”. It investigated the functions of code-switching as a communicative tool in English as a second language teacher education class in a tertiary institution in Malaysia. The findings showed that three types of code-switching known as tag switching, inter-sentential switching, and intrasentential switching were dominant in classroom communication between students and between students and the instructor. The study also found that English was the dominant language of communication while code switching was used to convey ideas in specific situations and to enhance solidarity in the first language.

In Indonesia, the study of code-switching comes from Hidayat (2012). In his research entitled "Analysis of Code Switching used by Facebookers", he tried to find out what types of code - switching occurred in the Facebookers`comments, how often did the code - switching types occurred in facebookers' comments and to find out the reasons why the Facebookers switch their language. Findings of the research showed that the Facebookers tended mostly to use 
Volume 4, Number 01, June 2018

inter-sentential switching then followed by intra-sentential switching and tag switching. The study also found the reason why the facebookers used codeswitching because of real lexical need, Talking about a particular topic and because of speech content clarification.

The previous researches above had some similarities to the research that the researcher conducted. The researcher used the same theory about the types of Code - switching as the researcher tried to analyze. The theory about types of code switching was taken from Poplack's model. The differences of this research from previous researches was in the focus of the researches. Most of the previous study took the research in the classroom, video movie or in social media while the researcher tried to take the English meeting club as the object of the research and focused on analyzing the kind of code- switching that occur in the English meeting club and the reason of the people in English meeting club used code-switching in their conversation based on Hoffmann Theory. So the researcher used the title "An Analysis of CodeSwitching in English Meeting Club (a Case Study in "Benteng Panynyua English Club" Fort Rotterdam, Makassar)

\section{B. REVIEW OF RELATED LITERATURES}

\section{Code-Switching Definition}

Poplack (1980) states that code-switching is the alternation of two languages within a single discourse, sentence or constituent. Hudson (1991) conceptualizes code-switching as a situation whereby a single speaker uses different language varieties at different times, a consequence of the existence of registers. While according to Hoffmann (1991), code-switching is that it in alternate use of two languages or linguistic varieties within utterance or during the same conversation.

One phenomenon in Sociolinguistics that has very close relationship to Code -Switching is Code - mixing. it is difficult to create a clear line between them. Hill \& Hill (1980) in Chaer \& Agustina (2004) even state that there is no hope to distinguish between code-switching and codemixing. However, some experts had tried to make distinction between them. Bokamba (1989 : 279) outlined that Code-Switching (CS) is inter-sentential switching while Code-Mixing (CM) is

intra-sentential switching. Thelander in Chaer \& Agustina (2004) pointed out that code-switching occurs when there is a switch from a clause of a language to a clause of another language in a speech event; but when clauses or phrases used in a speech event consist of hybrid clauses or 


\section{Juvrianto CJ An Analysis Of Code-Switching...}

hybrid phrases which not support their own language function, it is called Code-Mixing. Parallel with Thelander, Fasold (1984) tried to distinguish Code-Switching and Code-Mixing based on grammatical criteria. According to Fasold, if a clause that is used by someone has clearly grammatical structure of a language then followed by a clause using grammatical structure of another language, it is Code-switching.

Some literatures also offer different kinds of code-switching, but the most prominent one is the model proposed by Shana Poplack (1980). That kinds of Code-switching are the intersentential, the intra-sentential code-switching, and extra-sentential code switching or "tag switching".

\section{Types of Code Switching}

Poplack (1980) proposed three types of code switching. They are Extra-sentential switching (tag-switching), intra- sentential switching and inter- sentential switching.

a. Tag switching

Tag-switching or extra-sentential switching is inserting tag elements from one language into an otherwise monolingual discourse in another language (Koban, 2013). Due to the syntactic nature of tags, they can be inserted in many different places in an utterance without disturbing the syntactic order, e.g. you know, I mean, right?

\section{b. Intra-sentential switching}

Intra-sentential switching is switching from one language variety to another at the clause, phrase or word level within a single utterance (Koban, 2013). In other words, this type of Codeswitching occurs within a clause or sentence boundary, it occurs in the middle of a sentence.

c. Inter-sentential switching

According to Koban (2013), inter-sentential switching is characterized by a switch from one language variety to another outside the sentence or clause level. Inter- sentential switching occurs between sentences. It switches at a clause or sentence level.

\section{The Reason to do Code-Switching}

Hoffman (1991) classified the reasons to do code switching into seven points, they are as follow: 
Volume 4, Number 01, June 2018

\section{a. Talking about a particular topic}

People sometimes prefer to talk about a particular topic in one language rather than in another. Sometimes, a speaker feels free and more comfortable to express their emotions, excitements, or even anger in a language that is not their mother tongue (Hidayat, 2012).

b. Quoting somebody else

Hoffman (1991) suggested that "people sometimes like to quote a famous expression or saying of some well-known figures". People often switch their language when quoting someone especially quotation from their different native language.

\section{c. Being emphatic about something}

Someone who suddenly wants to be emphatic about something while talking using a language that is not his native tongue, he or she, either intentionally or unintentionally, will switch from his second language to his first language.

\section{d. Repetition used for clarification}

Sometimes a bilingual who wants to clarify his speech to be more understood by the listener, he will tend to use both of the languages that he masters saying the same utterance.

e. Speaker's personal involvement and desire to be well understood

When a bilingual talks to another bilingual, it was mentioned that there will be lots of code switching and code mixing that occur. It means making the content of his speech runs smoothly and can be understood by the hearer (Hoffman, 1991).

f. Expressing group identity

Code switching and code mixing can also be used to express group identity. The way of communication of academic people in their disciplinary groupings, are obviously different from other groups (Hoffman, 1991).

\section{RESEARCH METHODOLOGY}

This research investigates the kinds of code-switching that the learners used in English meeting club; in this case, Rotterdam English Meeting Club. The study uses descriptive qualitative as the method. The researcher obtains the conversations between members of the meeting club. The researcher provides the data in video or audio recording. The data were taken from the conversations among participants containing code -switching. 


\section{Juvrianto CJ An Analysis Of Code-Switching...}

The members of the English Meeting Club were about $7-10$ participants in a circle. The researcher took three circles to be recorded. Every circle has one leader who provide the issue and manage the turn-taking and time. The English meeting club took an hour to finish an issue every week.

The data collections were done as follows: first, the researcher recorded the process of English meeting club in Fort Rotterdam, Makassar. Second, the researcher converted the video conversation into transcription. Later, the researcher will analyze the kind of code-switching and the reasons to do code-switching in transcription.

\section{FINDINGS AND DISCUSSION}

This part presents the types of code switching used by the members of the English Meeting Club. The code switching in the data were divided into three categories of types, tag-switching, intra-sentential switching and inter-sentential switching.

\section{Tag-switching}

Tag-switching or extra-sentential switching is inserting tag elements from one language into an otherwise monolingual discourse in another language (Koban, 2013). Due to the syntactic nature of tags, they can be inserted in many different places in an utterance without disturbing the syntactic order.

\section{Extract 1}

The conversation was taken from second circle of English Meeting Club

Leader : okay now, we start our discussion from number one. How important car for you guys? Hmmm. Maybe you first.

Speaker $1 \quad$ : for me, car is very important. Eehb we can use for go anywhere. For far distance. Yyahb I think

Leader $\quad$ : so for you car is very important

Speaker 1 :yes?

Leader : very important?

Speaker 1 : iya, very important.

In extract 1, the speaker 1 asked the speaker 2 to repeat the answer whether car is important to her or not. Speaker 2 repeat and confirm her answer by using "iya" in Indonesian 
Volume 4, Number 01, June 2018

then switch it into English. the word "iya" here belongs to the sentence filler and the existence of the word does not disturb the syntax order of the sentence, so it is a kind of "tag-switching".

\section{Extract 2}

The conversation was taken from second circle of English Meeting Club

Leader : there is no traffic jam?

Speaker $6 \quad$ : eee no no, if there is traffic jam, you can ee apa.. you can pass the the cars yeah easily. because ee yeah there is usually in the morning and afternoon maybe eee people eee apa to go to office and back from office. Eee itu ee jam - jam sibuk apa lagi? Ee yeah eein the morning and afternoon there many traffic jam you can find so that ee actually ee car is in the beginning, car is ee to make people feel easy yeah, but right now, I, ee myself feel that car make people yeabh star in the street.

In extract 2, the Leader ask whether car is the cause of traffic jam or not. And speaker 6 answer by using English in the first sentence and then using "apa" in Indonesian. "apa" is not including to the main sentences or not disturbing the syntactic order of those sentences, so it belongs to the "tag-switching" phenomenon.

\section{Intra-sentential switching}

Intra-sentential switching is a type of Code-switching that occurs within a clause or sentence boundary, it occurs in the middle of a sentence.

\section{Extract 3}

This conversation was taken from first circle of English Meeting Club

Leader : ob okay, so you prefer a private car. Okay. Number four do you think that private car is the main problem of traffic jam in Makassar?

Speaker $1 \quad$ :ee it's not really the main problem, but the most ee but I think sometimes eee traffic jam ee in Makassar because a car but not really I mean not really the car but sometimes the car. The problem is the people who not to obey ee mematuhi the eee obey the rules. I think it's that

In extract 3, Speaker 1 use sentence "The problem is the people who not to ee mematubi the eee [obey] the rules". In this case, the context is speaker 1want to repeat her word in order to make clear what she say and the hearer easy to understand her sentence. So she switched her word into Indonesian. The word "mematuhi" here is as verb of the sentence, so, it is kind of intra-sentential switching.

\section{Extract 4}

The conversation was taken from first circle of English Meeting Club 


\section{Juvrianto CJ An Analysis Of Code-Switching...}

Leader : Costly I mean more costly because... e you have to buy eee like bensin right? It really taking money oke move to you

Speaker $2 \quad$ :for me the advantages having car.. it is you said that it can brings goods more than by driving motorcycle and it make us save such as from hot, then the disadvantages it's lebih mahal ...more expensive because we need more viewer more space in the road so it causes the jam maybe I think that's

In extract 4, Intra-sentential switching occurs twice, the first is when the leader say "you have to buy eee like bensin, right?". The second is when speaker 2 says 'it's lebih mahal' in this case, both of speakers switch their words into Indonesian because they don't know the English of the words. they switch them in order to make clear what she want to say and all of the speakers can understand her sentence. The switching from English to Indonesia above occurs in the sentence boundary, they are intra-sentential switching.

\section{Extract 5}

The conversation was taken from the third circle of English meeting

Leader : what about you?

Speaker $1 \quad$ : I think the advantage motor gycle is it's so simply and we didn't get traffic jam but the disadvantages from ammm motor cycle we easy get aaa accident in the street. And aamm we can a kena pollution.

In Extract 5, speaker did intra-sentential code-switching. It involved single-word level. intra-sentential switching was found almost in every sentence using by all of speakers.

\section{Inter-sentential Switching}

Inter- sentential switching occurs between sentences. It switches at a clause or sentence level. In which each clause or sentence is in different language.

\section{Extract 6}

The conversation was taken from second circle of English Meeting Club

Leader : ob okay, so it is very important. Oke. Next you.

Speaker 5 : bisa diartikan kak?

Leader $\quad$ : eeh oke. Seberapa pentingnya mobil buat kamu. You can combine in English and Indonesian. Oh please guys, if I have some mistakes, you can correct me because me and you are learning together. I am not perfect too. I am here to learn too, like you guys. Okay, eee I have eee I am make mistake, you can correct me okay?

All speakers : :yes!!!

In extract 6, when the leader says "Seberapa pentingnya mobil buat kamu. You can combine in English and Indonesian", she uses Indonesian to make clear her question. The context of 
Volume 4, Number 01, June 2018

the conversation above is the speaker 5 is still poor in English, so the leader tries to use Indonesian to help her then switch it back to English to invite the speaker 5 try to use English. the switching occurs between the sentences Seberapa pentingnya mobil buat kamu and You can combine in English and Indonesian. the sentences has their own grammatical function of its own language; So it can be concluded it is a kind of Inter-sentential switching

\section{Extract 7}

The conversation was taken from second circle of English Meeting Club

Speaker 6 : tax yah? Tax you know like ee cigarette now is become expensive because eee government took the tax very high. So don't let people buy car easily eee the car automatically eee apa... will eee more or less ee apa ee lebih sedikit yah. And right now you ee there are many eee apa ee cheap car yeah. So that yeah cheap car ee is below hundred million. So the ee people that ee who have money they can buy. Apa sib ee. mereka ee ee apa bisa mencicil begitu. And yeah I will support if ee government our government eee build our public transportation eee not only to drive have to good skill in driving but they have to know the rule of driving yeah, because you see that eee traditional eee driver has good skill yeah, they can move iig rag yeah. But they don't know the rule yah. Actually they have a good skill in driving but they don't ehh apasih mengabaikan. Yah the attitude of the driver is not good in Makassar. but eeh yah I think they have good skill in driving but they don't have good attitude in in the street. Yeah I will support public transportation because ee by using eee big car, there many people can eee took in that bus of course eee our street that will eee more apa more easy to access.

In extract 7, speaker 6 does code switching more than once, he tends to do tag-switching by using "apa" repeatedly and intra - sentential switching by using single-word switching like "mengabaikan". The inter- sentential switching occurs when he says "So the ee people that ee who have money they can buy. Apa sib ee. mereka ee ee apa... bisa mencicil begitu'. The speaker was talking by using English and then switch it into Indonesia and we can see that both of sentences still keep their own grammatical function.

After presented and analyzed the data, the researcher found that there are three types of code-switching is used by the members of the English meeting club. Those are Tag-switching, intra-sentential switching and inter-sentential switching. Tag switching was occurred in extract 1 and 2. Intra- sentential switching was found in Extract 3, 4 and 5. And inter-sentential switching was found in extract 6 and 7.

Code switching above was occurred as alternation of two codes and done by some reasons. By analyzing the data, researcher found that the most of the speakers did code-switching because 
they were lack of vocabularies and they tried to switch their words to keep their communication so that the other speakers understand what they tried to communicate. It suits on Hoffmann theory about "why do bilingual code-switches?" in point (d) Repetition used for clarification and (e) Speaker's personal involvement and desire to be well understood.

\section{Data Display}

\begin{tabular}{|l|l|l|c|}
\hline No & $\begin{array}{c}\text { Code-Switching } \\
\text { Types }\end{array}$ & \multicolumn{1}{|c|}{ Example } & Extract \\
\hline I & $\begin{array}{c}\text { Extra-sentential } \\
\text { Switching (tag- } \\
\text { switching) }\end{array}$ & $\begin{array}{l}\text { iya, very important. } \\
\text { you can ee apa.. you can pass the the cars yeah } \\
\text { easily. }\end{array}$ & 2 \\
\hline 2. & $\begin{array}{c}\text { Intra-sentential } \\
\text { switching }\end{array}$ & $\begin{array}{l}\text { The problem is the people who not to obey ee } \\
\text { mematuhi the eee obey the rules. } \\
\text { it's lebih mahal ...more expensive because we } \\
\text { need more viewer more space in the road } \\
\text { And aamm we can aa kena pollution }\end{array}$ & 3 \\
\hline 3. & $\begin{array}{l}\text { Inter-sentential- } \\
\text { switching }\end{array}$ & $\begin{array}{l}\text { Seberapa pentingnya mobil buat } \\
\text { kamu. You can combine in English and } \\
\text { Indonesian. } \\
\text { So the ee people that ee who have } \\
\text { money they can buy. Apa sib ee. mereka } \\
\text { ee ee apa... bisa mencicil begitu }\end{array}$ & 4 \\
\hline
\end{tabular}

\section{E. CONCLUSION AND SUGGESTION}

Based on what the research focused on, data presentation and analysis. The researcher can conclude that there are three types of code switching occurred during the English club meeting. They are tag-switching, intra-sentential switching and inter- sentential switching as Poplack Proposed. Those code switching are done by some reasons to keep their communication so that the other speakers understand what they try to communicate. It suits on Hoffmann theory about "why do bilingual code-switches?" in point (d) Repetition used for clarification and (e) Speaker's personal involvement and desire to be well understood. 
Volume 4, Number 01, June 2018

This mini research has some limitations. it only presented some examples of each kind of Code-switching and only observed three circle of the English meeting club without comparing Code-switching that occurred in each circle. So it is suggested to the next researchers to take more than three circles of English meeting club, and then compare their result in order to give more understanding to the reader about a phenomenon called "Code-Switching" that may occur in Bilingual or multilingual communities.

\section{REFERENCES}

Azlan N. M. N. I \& Narasuman, S. (2013). The Role of Code-Switching as Communicative Tool in an ESL Teacher Education Classroom. Procedia - Social and Behavioral Sciences 90. 458467.

Bokamba, E.,(1989) Are there syntactic constraints on code-mixing? World Englishes 8, 277- 292.

Chaer, A. \& Agustina, L. (2004). Sosiolinguistik: Perkenalan awal. Jakarta: PT. Rineka Cipta.

Hidayat., T. (2012) Analysis of Code Switching used by Facebookers English. Bandung: Sekolah Tinggi Keguruan dan IlmuPendidikan (STKIP) Siliwangi .

Hoffman, C. (1991). An Introduction to BilingualismNew York: Longman.

Hudson, R. A. (1980). Sociolinguistics. Melbourne: Cambridge University Press.

Koban, D. (2013). Intra-Sentential and Inter-Sentential Code-Switching in Turkish-English Bilinguals in New York City, U.S. Procedia - Social and Behavioral Sciences 70. 1174- 1179.

Liu, L. (2003). A New Perspective on the Goals of TEFL in China. Retrieved 11 May 2016, from http://iteslj.org/Articles/Liu-Goals.html

Nur, N. A. (2015). A Descriptive Analysis Of English Indonesian Code Switching Spoken By The Teacher In The First Grade Of MTSN Model Makassar. ETERNAL (English, Teaching, Learning, and Research Journal), 2(1), 82-95.

Nurpahmi, S. (2013). An Introduction to English for Specific Purposes. Makassar: Alauddin University Press.

Nurpahmi, S. (2014). English for Specific Purposes: An Integrated Approach. Makassar: Alauddin University Press.

Nurpahmi, S. (2017). ESP Course Design: An Integrated Approach. Lentera Pendidikan: Jurnal Ilmu Tarbiyah Dan Keguruan, 19(2), 172-181. 
Juvrianto CJ An Analysis Of Code-Switching...

Nurpahmi, Sitti and Rahman, Muhammad Asfah and Salija, (2018). Bilingual-based Instruction in Teaching English for Academic Purposes at Islamic University. Journal of Language Teaching and Research. Volume 9(3), 620-628. DOI: http://dx.doi.org/10.17507/jltr.0903.23

Nurpahmi, S. (2017). Teacher Talk In Classroom Interaction. ETERNAL (English, Teaching, Learning, and Research Journal), 3(1). 34-43. DOI: https://doi.org/10.24252/Eternal.V31.2017.A4.

Poplack, S. (1980). Sometimes I'll start a sentence in English y termino en espanol: toward a typology of codeswitching. Linguistics, 18, 581-616.

Poplack, S. (2001). Code-switching (Linguistic). In Smelser, Niel \& Baltes, Paul (eds), International Encyclopedia of the Social and Behavioral Sciences. Elsevier Science Ltd. 2062- 2065 